$$
\begin{array}{ccccccc}
\text { L } & \text { E } & \text { T } & \text { u } & \text { v } & \text { о } & \text { s } \\
\hline \text { ARCHEOlogija } & 47
\end{array}
$$



Lietuvos istorijos institutas

\begin{tabular}{llllllll}
$\mathrm{L}$ & $\mathrm{I}$ & $\mathrm{E}$ & $\mathrm{T}$ & $\mathrm{U}$ & $\mathrm{V}$ & $\mathrm{O}$ & $\mathrm{S}$ \\
\hline
\end{tabular}

ARCHEOlogija 47 


\section{Leidybą finansavo}

\section{LIETUVOS MOKSLO TARYBA}

PAGAL VALSTYBINĘ LITUANISTINIŲ TYRIMŲ IR SKLAIDOS 2016-2024 METŲ PROGRAMĄ

(Finansavimo sutarties numeris S-LIP-19-4)

\section{Redaktorių kolegija / Editorial board:}

Atsakingoji redaktorė / Editor-in-chief dr. Agnè Čivilytė (Lietuvos istorijos institutas, Vilnius / Lithuanian Institute of History, Vilnius)

Atsakingosios redaktorès pavaduotoja / Assistant Editor dr. Elena Pranckènaitè (Lietuvos istorijos institutas, Vilnius / Lithuanian Institute of History, Vilnius)

Dr. Laurynas Kurila (Lietuvos istorijos institutas, Vilnius / Lithuanian Institute of History, Vilnius)

Dr. Valdis Bērziņš (Latvijos universitetas, Latvijos istorijos institutas, Ryga / University of Latvia, Institute of Latvian History, Riga)

Habil. dr. Anna Bitner-Wróblewska (Valstybinis archeologijos muziejus Varšuvoje, Lenkija / State Archaeological Museum in Warsaw, Poland)

Dr. Christoph Jahn (Baltijos ir Skandinavijos archeologijos centras, Šlèzvigas, Vokietija / Center for Baltic and Scandinavian Archaeology, Schleswig, Germany)

Prof. dr. Rimantas Jankauskas (Vilniaus universitetas, Lietuva / Vilnius University, Lithuania)

Akad. prof. dr. Eugenijus Jovaiša (Lietuvos mokslu akademija, Vilnius / Lithuanian Academy of Sciences, Vilnius)

Habil. dr. Bartosz Kontny (Varšuvos universitetas, Archeologijos fakultetas, Lenkija / Faculty of Archaeology, University of Warsaw, Poland)

Prof. dr. Valter Lang (Tartu universitetas, Estija / University of Tartu, Estonia)

Doc. dr. Algimantas Merkevičius (Vilniaus universitetas, Lietuva / Vilnius University, Lithuania)

Habil. dr. Tomasz Nowakiewicz (Varšuvos universitetas, Archeologijos fakultetas, Lenkija / Faculty of Archaeology, University of Warsaw, Poland)
Habil. dr. Grzegorz Osipowicz (Mikalojaus Koperniko universitetas, Torunè, Lenkija / Nicolaus Copernicus University, Toruń, Poland)

Dr. Gytis Piličiauskas (Lietuvos istorijos institutas, Vilnius / Lithuanian Institute of History, Vilnius)

Dr. Eve Rannamäe (Tartu universtitetas, Estija / University of Tartu, Estonia)

Dr. Andra Simniškyte (Lietuvos istorijos institutas, Vilnius / Lithuanian Institute of History, Vilnius)

Dr. Roberts Spirgis (Latvijos universitetas, Latvijos istorijos institutas, Ryga / University of Latvia, Institute of Latvian History, Riga)

Dr. Eugenijus Svetikas (Lietuvos istorijos institutas, Vilnius / Lithuanian Institute of History, Vilnius)

Dr. Andris Šnē (Latvijos universitetas, Ryga / University of Latvia, Riga)

Doc. dr. Gintautas Zabiela (Klaipédos universitetas, Lietuva / Klaipéda University, Lithuania)

Prof. dr. Šarūnas Milišauskas (Niujorko valstijos Bafalo universitetas, JAV / New York State University at Buffalo, USA)

Prof. dr. Timothy Chevral (Niujorko valstijos Bafalo universitetas, JAV / New York State University at Buffalo, USA)

Prof. dr. Johan Ling (Gioteborgo universitetas, Švedija / University of Gothenburg, Sweden)

Sekretorè / Secretary Dovilè Urbonavičiūtė-Jankauskienė

Redakcijos adresas / Editorial Board address:

Lietuvos istorijos institutas, Archeologijos skyrius

Tilto g. 17, LT-01101 Vilnius

Tel. (+370) 5 2614436, fax (+370) 52611433

e-mail: lietuvosarcheologija@gmail.com; civilytea@gmail.com

\section{Žurnalas registruotas: EBSCO Publishing: Central and Eastern European Academic Source European Reference Index for the Humanities and Social Sciences (ERIH PLUS)}




\section{TURINYS / CONTENT}

Agnè Čivilytė

Ernestine S. Elster

James Patrick Mallory
PRATARME் 7

FOREWORD 11

\section{MARIJA GIMBUTIENE் KAIP ASMENYBE் / MARIJA GIMBUTAS AS PERSONALITY}

MARIJA GIMBUTAS, HER EXCAVATIONS, AND THE CONCEPT OF OLD EUROPE / MARIJA GIMBUTIENĖ, ARCHEOLOGINIAI KASINĖJIMAI IR SENOJI EUROPA .15

MARIJA GIMBUTAS IN THE CLASSROOM, FIELD AND OFFICE: A SHORT PERSONAL REMINISCENCE / MARIJA GIMBUTIENE KLASĖJE, KASINĖJIMUOSE IR KABINETE: TRUMPI ASMENINIAI PRISIMINIMAI .31

Kornelija Jankauskaitė MARIJA GIMBUTIENÉ: KELIAUTOJA IR TYRĖJA / MARIJA GIMBUTAS: TRAVELLER AND RESEARCHER .43

\section{STRAIPSNIAI / ARTICLES}

Šarūnas Milišauskas MARIJA GIMBUTAS (GIMBUTIENĖ): THE BALTIC GODDESS .55 MARIJA GIMBUTIENĖ: BALTŲ DEIVE். .88

Julia Mattes

ANTHROPOMORPHIC FIGURINES, GYNOCENTRISM AND GIMBUTAS' RECEPTION INSIDE ARCHAEOLOGY AND BEYOND .91

ANTROPOMORFINĖS FIGŪRĖLĖS, GINOCENTRIZMAS IR MARIJOS GIMBUTIENĖS IDĖJOS ARCHEOLOGIJOJE BEI UŽ JOS RIBŲ 123

MELLAART, GIMBUTAS, GODDESSES, AND ÇATALHÖYÜK: EARLY ASSUMPTIONS AND RECENT PERSPECTIVES ON THE ÇATALHÖYÜK FINDS 125

MELLAARTAS, GIMBUTIENĖ, DEIVĖS IR ČATAL HIUJUKAS: PIRMOSIOS PRIELAIDOS IR NAUJAUSIA RADINIŲ IŠ ČATAL HIUJUKO APŽVALGA 143 
Sharada Srinivasan

Rasa Banytè-Rowell

Florin Gogâltan

Gytis Piličiauskas Edvardas Simčenka Justina Kozakaitè Žydrūnè Miliauskienė Giedrè Piličiauskienè Harry Kenneth Robson

Janusz Czebreszuk Agnè Čivilytė

Paulius Gritènas

Artūras Dubonis
GODDESS WORSHIP AND THE DANCING FORM: EXPLORING RITUAL IN INDIAN PREHISTORY AND SOUTH INDIAN ANTIQUITY 145 DEIVĖS GARBINIMAS IR ŠOKIO JUDESIO FORMA: RITUALAI INDIJOS PRIEŠISTORĖJE IR PIETŲ INDIJOS ANTIKOJE 164

MARIJA GIMBUTAS’ DISSERTATION AND ITS VALUE:

BURIAL CUSTOMS IN THE ROMAN IRON AGE. 167 MARIJOS GIMBUTIENĖS DISERTACIJA IR JOS SVARBA: ROMĖNIŠKOJO LAIKOTARPO LAIDOSENA 185

TRANSYLVANIA AND THE OF INDO-EUROPEAN MIGRATION PROBLEM. THE ROMANIAN PARADIGM 187 TRANSILVANIJA IR INDOEUROPIEČIŲ MIGRACIJOS PROBLEMA. RUMUNIJOS PARADIGMA 207

DONKALNIO IR SPIGINO KAPINYNŲ AKMENS AMŽIAUS ŽMONIŲ KILMÉ IR MOBILUMAS STRONCIO IZOTOPŲ ANALIZĖS DUOMENIMIS. 209

THE ORIGINS AND MOBILITY PATTERNS OF STONE AGE HUMANS FROM THE DONKALNIS AND SPIGINAS BURIAL GROUNDS ACCORDING TO STRONTIUM ISOTOPE ANALYSIS. . .232

PROFESSOR MARIJA GIMBUTAS' ADVENTURE WITH PREHISTORIC AMBER AND THE RESULTS FOR US. 235 MARIJOS GIMBUTIENÉS PRIEŠISTORINIO GINTARO TYRINĖJIMAI IR JŲ REIKŠMĖ ŠIANDIEN 247

\section{KITAIP APIE ARCHEOLOGIJĄ /} ALTERNATIVE PERCEPTIONS OF ARCHAEOLOGY

FILOSOFIJA KAIP ARCHEOLOGIJA 249

\section{RECENZIJOS / REVIEWS}

RYTIS JONAITIS, IRMA KAPLŪNAITE்.

SENKAPIS VILNIUJE, BOKŠTO GATVËJE. XIII-XV A.

LAIDOSENOS LIETUVOJE BRUOŽAI. .253

AUTORIŲ DE்MESIUI 259

GUIDELINES FOR AUTHORS 263 


\title{
MARIJA GIMBUTAS, HER EXCAVATIONS, AND THE CONCEPT OF OLD EUROPE
}

\author{
ERNESTINE S. ELSTER
}

\begin{abstract}
Cotsen Institute of Archaeology, UCLA, 308 Charles E. Young Drive North, A210 Fowler Building/Box 951510, Los Angeles,
\end{abstract} CA 90095-1510, e-mail: eelster@ucla.edu

Many thanks to Agnė Čivilytė and her Committee for the invitation to participate in honouring Marija Gimbutas: mentor, colleague, and friend. The conference (Vilnius 2021) was aptly named Marija Gimbutas in the World and discussed her many accomplishments in archaeology, historical linguistics, folklore, mythology, Baltic and Slavic history and prehistory, Indo-European studies, and more.

My focus is on her archaeological contributions, including her arrival and involvement at UCLA, and her research publications before she organized an excavation in southeast Europe. Marija Gimbutas' 'kurgan' hypothesis, i.e. the Early Bronze Age arrival in Europe and the impact of ${ }^{\star}$ Proto-IndoEuropean speakers with their mound (kurgan) burials, which was first presented in a 1956 meeting of the International Council of Ethnological Sciences in Philadelphia. She continued this research for many decades and the hypothesis has recently been given renewed acceptance because of aDNA studies. It had been debated for decades, especially as Marija Gimbutas interpreted ${ }^{\star} \mathrm{PIE}$ as male dominated and the opposite of the earlier Neolithic Chalcolithic Old Europe (see especially Kokkinidou 2020, 68-81).

My attention here is on 'Old Europe', one of her most original contributions, introduced in 1972 and identified as the large region of Neolithic and Chalcolithic settlements in southeast Europe and

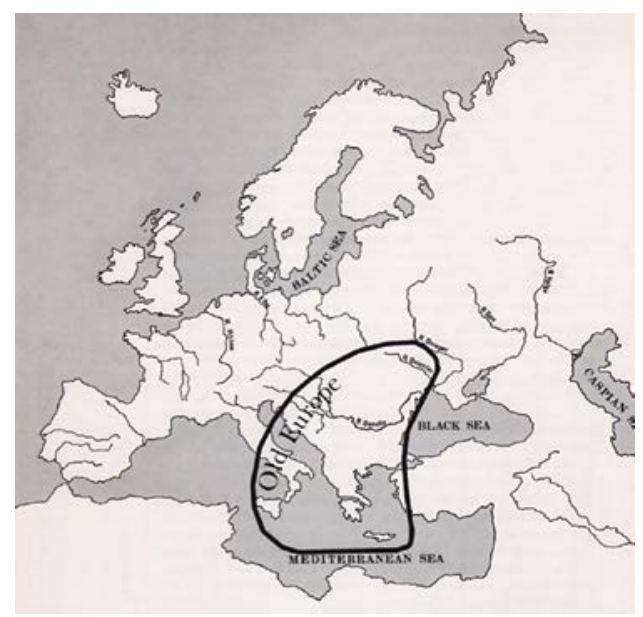

Fig. 1. A map of Old Europe (after Gimbutas 1974, 16, Map I). 1 pav. Senosios Europos žemèlapis (pagal Gimbutas 1974, 16, I žemèlapis).

the Balkans, from the Adriatic to the Mediterranean and Aegean, north to Poland and east to the Dnieper (Fig. 1). The five sites she excavated in Old Europe are described; particular attention being given to an Old Europe exemplar, Sitagroi, with its long sequence of radiocarbon dates: Middle Neolithic to Early Bronze Age. I conclude with a summary of the debates concerning the large group of small clay figurines Marija Gimbutas identified in her publications as Old Europe's pantheon of gods and goddesses (Gimbutas 1974c; 1982) which introduced considerable controversy, inspired new research, and fascinating current developments. 


\section{RESEARCH: HARVARD AND UCLA}

At Harvard her research produced many articles, too many to list here (but see Elster 2007), and two important monographs: the first (Gimbutas 1956) on the prehistory of the Baltic area and Russia, followed by the Bronze Age of Central and Eastern Europe (Gimbutas 1965), a magisterial study. These volumes plus her countless journal articles and published conference proceedings provided her with a healthy publication history and recognition as an especially talented and knowledgeable European prehistorian: the leading western scholar of an area not at all well known at that time. When she arrived at UCLA in 1963 via a year at Stanford's Center for Advanced Studies, Bronze Age was in press; she was appointed Associate Professor and was promoted a year later to Full Professor, serving from 1964 to her retirement in 1989, in Classics, Slavic Studies, and Indo-European Studies with classes, seminars, and lectures on Baltic and Slavic Folklore and on Europe's Neolithic and Bronze Age, was appointed Curator of the Laboratory of Old World Archaeology (the Wellcome Collection had come to UCLA's Museum), and was a prime mover in the establishment of the Interdepartmental Graduate Program in Archaeology (1969), the Institute of Archaeology (1973), and the Journal of Indo-European Studies, which was introduced in the Spring of 1973 and continues to this day. We listened in her UCLA lecture classes and seminars on the Neolithic and Chalcolithic in Europe and the Near East to systematic, enthusiastic illustrative presentations based on original site reports from Greece, the Former Republic of Yugoslavia, Bulgaria, Romania, Hungary, Turkey, Italy, Moldova, Ukraine, etc. She regularly covered the geography, site location, settlement system, architecture, technology, economy, burial rites, cult objects, pottery styles, and questions of trade or exchange. Her archaeology seminars and lectures were based on an enormous amount of personal research initiated in Europe, intensified during her years at Harvard, and continued apace at UCLA plus a voluminous correspondence with colleagues abroad; attendance and participation at conferences in the US and overseas; and the photographing of sites, artefacts, and assemblages in museums, institutes, and in the field.

\section{THE EXCAVATIONS}

I visited her first excavation at Obre (Benac 1973; Gimbutas 1974a) and participated as a graduate student at Sitagroi (Renfrew et al. 1986; Elster, Renfrew 2003), Anzabegovo (Gimbutas 1976), and Achilleion (Gimbutas et al. 1989). In 1980 Marija and I co-directed the Grotta Scaloria study season in Manfredonia. Marija Gimbutas was committed to the dissemination of excavation results in every way; four were fully published in her lifetime and the fifth, Grotta Scaloria, appeared posthumously (Elster et al. 2016). Marija had a high respect for scientific contributions to excavations: radiocarbon dating (and the corrections curve), palaeozoology, (Sandor Bökönyi (1974) analyzed the faunal components at each of the five excavations), and palaeobotany (especially Jane Renfrew) while geologists, geographers, and other specialists were regularly included. After Obre, it is likely she chose the location of each excavation in order to examine firsthand the archaeology in various regions of southeast Europe (Fig. 2). Marija was interested in a regional picture; each excavation, radiocarbon dated, filled in and rounded out her synthesis of Early Neolithic - Chalcolithic Old Europe.

Obre: With Alojz Benac, the Director of Sarajevo's Zemalski Museum, Marija opened Obre in Bosnia in 1967 together with students from both their institutions. Marija's UCLA team and Benac's approached excavation differently. UCLA was looking for New Archaeology's quantitative sample (Binford 1962); Benac' goal was the exposure of house remains and settlement plans, thus the two teams excavated 


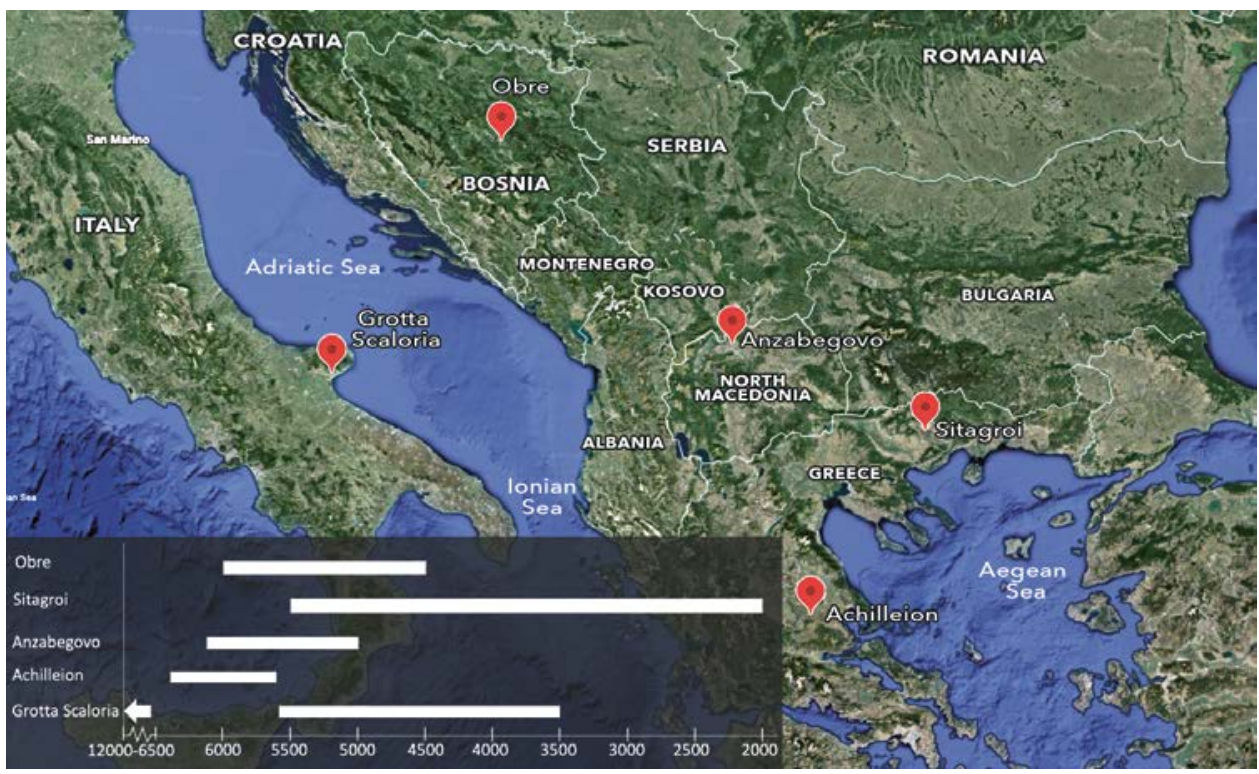

Fig. 2. A map of the excavation sites. Radiocarbon dating of the sites (Renfrew et al. 1986, 173, Table 73). Drawing by Abhishek Goel. 2 pav. Vietovių, kur buvo vykdomi archeologiniai tyrimai, žemèlapis. Taip pat radioaktyvosios anglies metodu nustatytos šių vietovių datos (Renfrew et al. 1986, 173, 73 lentelè). Abhishek Goel pieš.
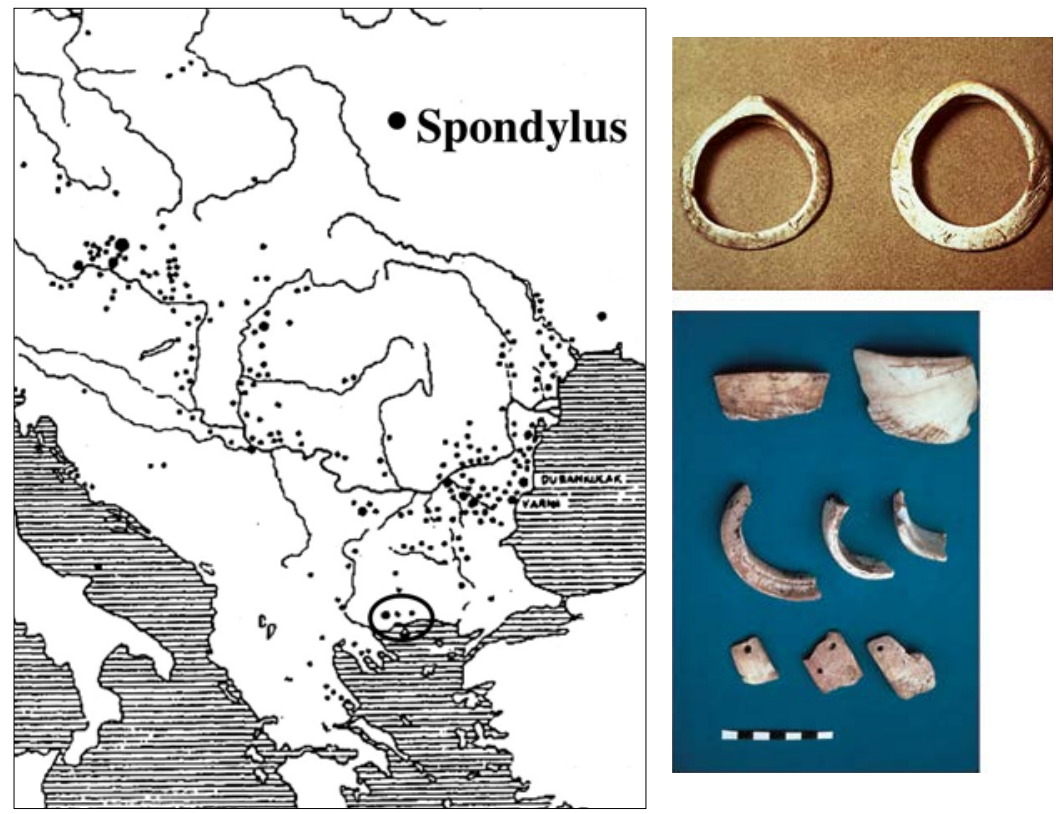

Fig. 3. Bracelets, pendants and fragments of Spondylus, which were sourced in the Aegean and exported/traded north. Photos of amulets, etc. - Elster 2006, Plate V. Drawing by Abhishek Goel.

3 pav. Apyrankès, pakabukai ir Spondylus kriauklių fragmentai, surinkti Egèjo jūroje ir eksportuoti į šiaurę ar joje parduoti. Nuotraukos pagal Elster 2006, V lentelè. Abhishek Goel pieš. 

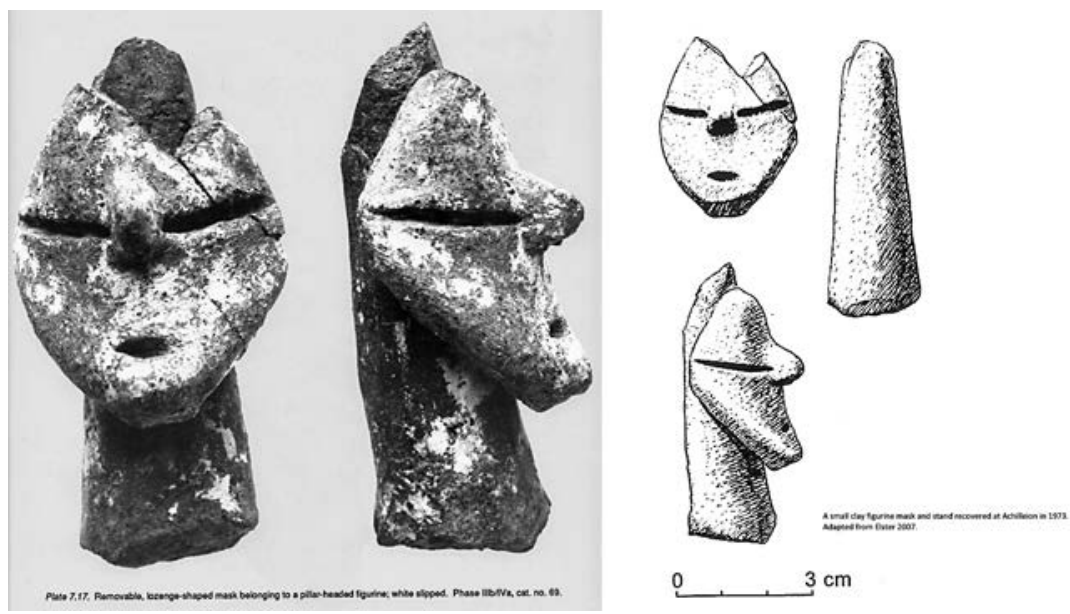

Fig. 4. Achilleion: a miniature mask on a pillar (Gimbutas et al. 1989, 357, Pl. 7.17.)

4 pav. Mažytė kaukè (nuimama ir uždedama ant laikiklio). Achileonas (Gimbutas et al. 1989, 357, 7.17 lentele)).

side by side - separate and equal - publishing two volumes (Benac 1973; Gimbutas 1974a). Together these monographs provide a rich picture of Early Neolithic and Middle Neolithic life against which the many radiocarbon determinations could be measured. The teams worked together in subsequent excavations at Greece, FRY, and Italy.

Before departing for Obre, and during Renfrew's 1967 visiting lectureship at UCLA, they organized and planned the excavations at Sitagroi on the Drama plain in northeast Greece, some $25 \mathrm{~km}$ from the Aegean coast. Before discussing Sitagroi in detail, some remarks need to be made on Anza, Achilleion, and Grotta Scaloria, all of which reflect Old Europe.

Anza. Marija was awaiting the arrival of the permit to excavate what she expected was an Early Neolithic site, Anzabegovo, south of Skopje in what is now the Republic of North Macedonia. The project was in cooperation with Milutin and Draga Garasanin of the National Museum, Belgrade. Once underway with Gene Sterud as field director, as he had been at Obre (Sterud, Sterud 1974), she drove from southern Yugoslavia to northeast Greece to join the 1969 Sitagroi field season. Marija's skill was in conception, organization, and synthesis. She never claimed to be a field archaeologist but she knew what to hope for. Anza was an Early Neolithic site with radiocarbon determinations in the 7 th millennium and the excavation exposed important evidence of contact to the south: artefacts of the spiny oyster, spondylus, sourced in the north Aegean (Schackleton, Renfrew, 1970) in the form of amulet fragments (Fig. 3). Recovery of these small shell pieces underlined ideas about the adoption of plant and animal domestication from Greece into the Balkans since these artefacts offered evidence of the necessary contact as early as the 7th millennium. Anza and Old Europe were formally introduced to the public in an article in Archaeology; its title, Excavation at Anza, Macedonia, further insight into the civilization of Old Europe, 7000-4000 BC (Gimbutas 1972), pointed to the site's importance to Marija Gimbutas' concept of Old Europe.

Achilleion. Subsequently, Marija, in synergesia with the Greek Archaeological Service represented in 1973 by Dimitrios Theochares and in 1974 by Kostas Gallis, opened Achilleion, a gently rising mound, one of many in the Greek Thessalian plain. Political issues closed all foreign excavation projects in the second year, 1974. Nevertheless, the results, as was evident 


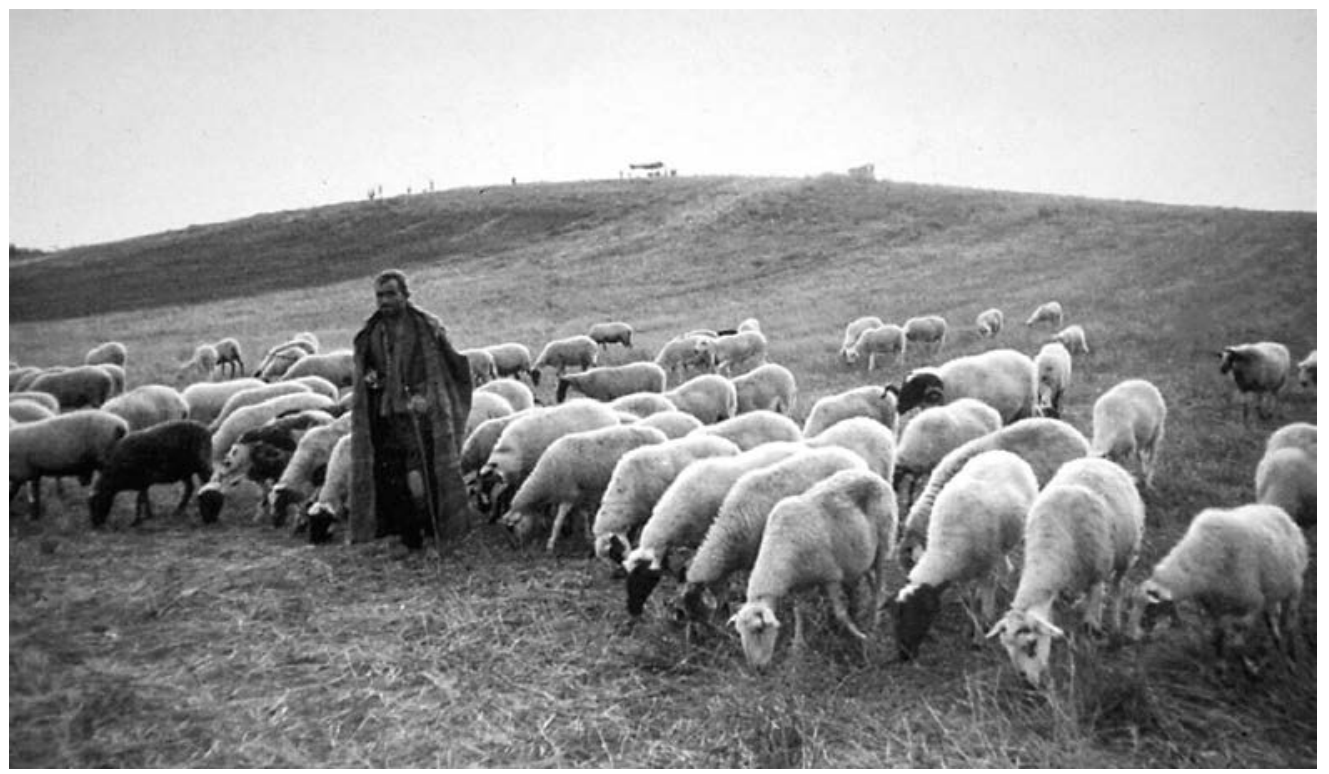

Fig. 5. Sitagroi mound before its excavation as seen from the north at sunrise. Photo by Robert Evans. 5 pav. Sitagroi kalva prieš archeologinius kasinejjimus tekant saulei. Vaizdas iš šiaurès. Roberto Evanso nuotr.

in the publication, were very rich in finds: evidence of economy, trade, craft, architecture, and hundreds of miniature and fragmented figurines. One find of baked clay was especially interesting: a little mask on a pillar or holder (Fig. 4). Marija concluded that Old Europe figurines were often depicted as masked (Gimbutas 1974b); this find clearly supported her analysis. Achilleion figured prominently in her regional description of Old Europe; its figurines were prominently included in the goddess volumes, creating considerable attention.

Grotta Scaloria, in Apulia, her final excavation, was opened in 1978 in cooperation with the highly respected prehistorian, Santo Tine, Professor of Prehistory at the University of Genoa and Director of the University's Institute of Experimental Archaeology. They planned a series of excavations to include the 'trincerati' of the Tavoliere Plain (Bradford 1949) and a new investigation of the cave which overlooked the Adriatic coast of Old Europe. The second field season, 1979 was followed by a study of the materials in Manfredonia in 1980 and then both Tine and Gimbutas moved on to other projects. But three decades later, I returned to Scaloria, urged on by John Robb, who reports on Scaloria in this Conference. With his help and an international group of scholars, we turned the legacy data into a published excavation report (Elster et al. 2016). It is an example of 'new wine in old bottles' for the aged data became the basis for expanded types of analyses and fresh information (Tafuri et al. 2016).

Sitagroi, (Fig. 5) the place of wheat, was a deep Greek mound which held 3000 years of occupational debris including the hallmarks of Old Europe: domestication becoming more focused over time: palaeobotany (Renfrew 2003); palaeozoology (Bökönyi 1986); trade, both local (spondylus: the Aegean Sea some $25 \mathrm{~km}$ distant (Nikolaidou 2003)) and long distance (flint from Madara, $300 \mathrm{~km}$ to the north (Tringham 2003, 107)); and crafts (pottery: control of the firing technique (Evans 1986) and wool production: mat and textile impressions as well as incised spindle whorls linked to sheep management (Elster 2004). 


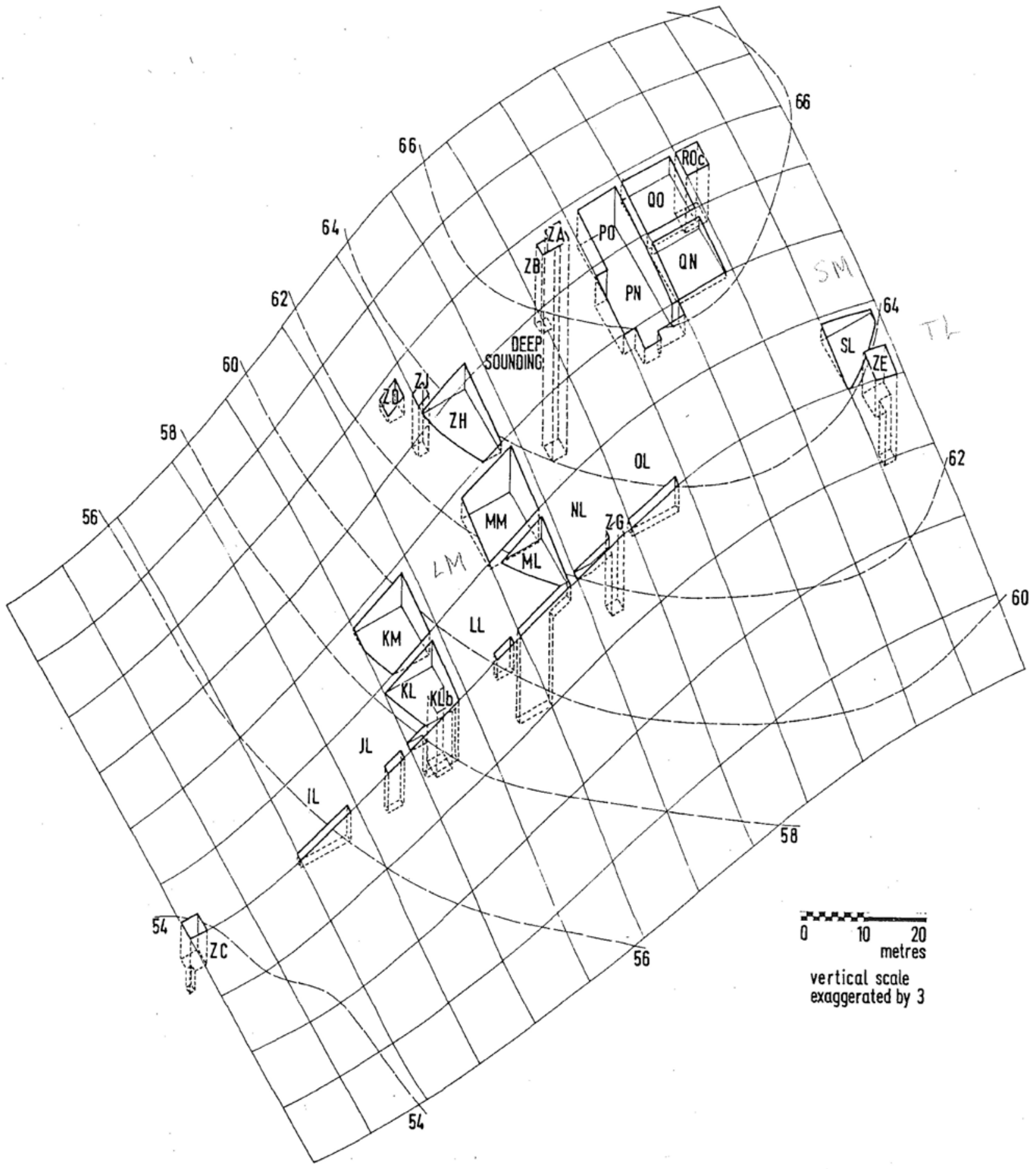

Axonometric view of the excavation area at Sitagroi indicating nomenclature of the excavated trenches.

Fig. 6. Excavation area (Renfrew et al. 1986, 18, Fig. 2.2).

6 pav. Kasinejjimų planas (Renfrew et al. 1986, 18, 2.2 pav.). 
The planned area of excavation was $40 \mathrm{~m}$ northsouth and $130 \mathrm{~m}$ east-west (Fig. 6). The $5 \mathrm{x} 5 \mathrm{~m}$ deep sounding, ZA, reached virgin soil at $10.5 \mathrm{~m}$ and allowed for the observation of soil variations, floor levels, and changes in pottery shapes and surface design, which last could be correlated with finds from other relative excavation units because Sitagroi was like a layer cake. The quantitative changes in the ZA pottery study produced a Middle Neolithic through Early Bronze Age (Fig. 7) chronology, Phases I-V, which was monitored with 29 radiocarbon determinations. Phase I pottery suggested a link to the north to Veselinovo, a Yugoslavian site with its recognizable pottery widely noted in the Balkans (Marriott 1986). Phase II continued this influence but added evidence of the coast (a trade in spondylus 'jewellery') and Thessalian painted pottery, clear proof of crafts and trade (ibid.). Phase III was marked by more spondylus and an explosion of graphite-painted and black-on-red pottery, both similar to finds at the nearby site, Dikili Tash (Fig. 8). Excavations had begun at this latter site in 1961 (Deshayes, Treuil 2004) and been continued by the French School of Archaeology in cooperation with the Greek Archaeological Service (Koukoulē-Chrysanthakē et al. 2008 ). The graphite painted and the black-onred pottery wares of Chalcolithic Sitagroi Phase III were first identified at Dikili Tash and thus reflect a
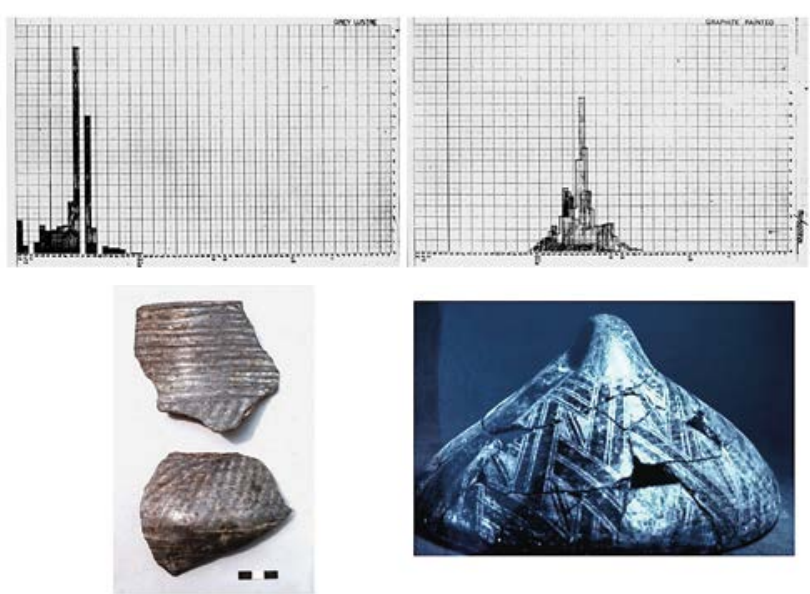

Fig. 7. A chart of pottery changes through time in Deep Sounding ZA based on counts; lower left, silvery ribbed, black Phase I/II; right, graphite painted large pottery lid Phase III (Renfrew et al. 1986, 166, Fig 7.16).

7 pav. Keramikos pokyčiai (remiantis ZA šurfo keramikos radiniais (vienetais)); kairejje pusejje apačioje - sidabriška, briaunota, juoda (I/II fazè); dešinèje - grafitu dekoruotas didelis keraminis indo dangtis (III fazè) (Renfrew et al. 1986, 166, 7.16 pav.).

Fig. 8. Two handled vessels decorated in Black on Red: left: Dikili Tash DT 150 (Deshayes, J., Treuil, R., 2004, Plate E); right: Sitagroi (Renfrew et al. 1986, 422).

8 pav. Du keraminiai indai su rankenèlèmis, dekoruoti juoda spalva ant raudonos. Indas kairejje aptiktas Dikili Taš (Deshayes, J., Treuil, R., 2004, E lentelè), dešinèje - Sitagroi (Renfrew et al. 1986, 422).

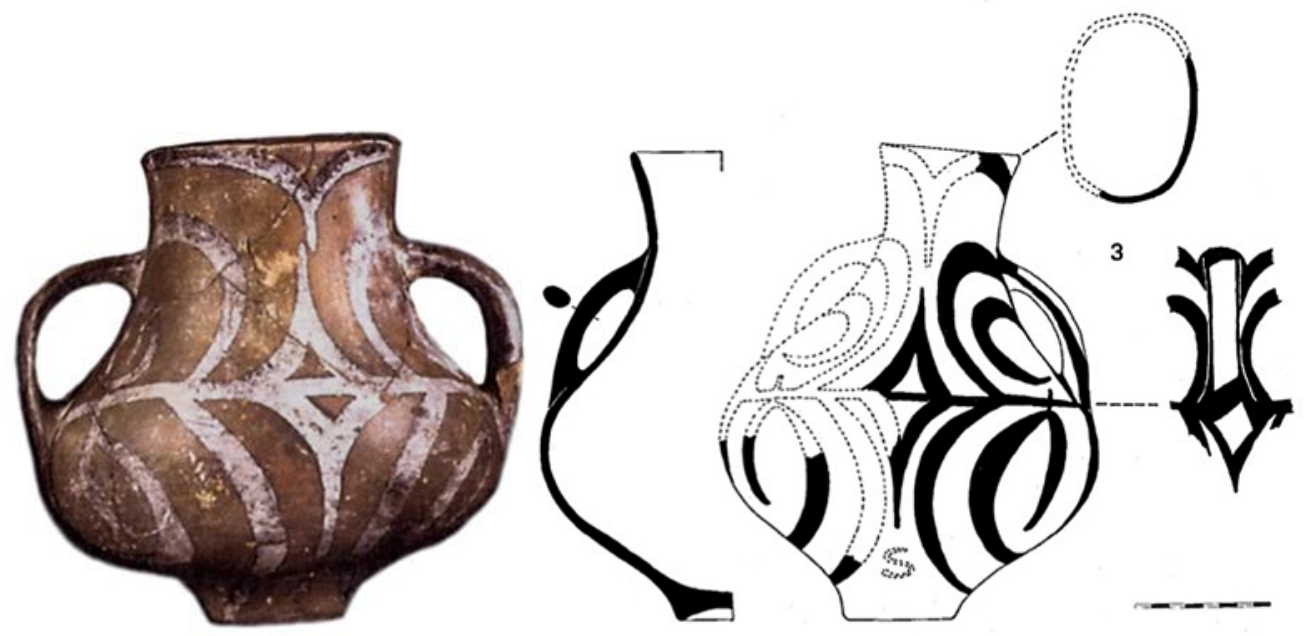




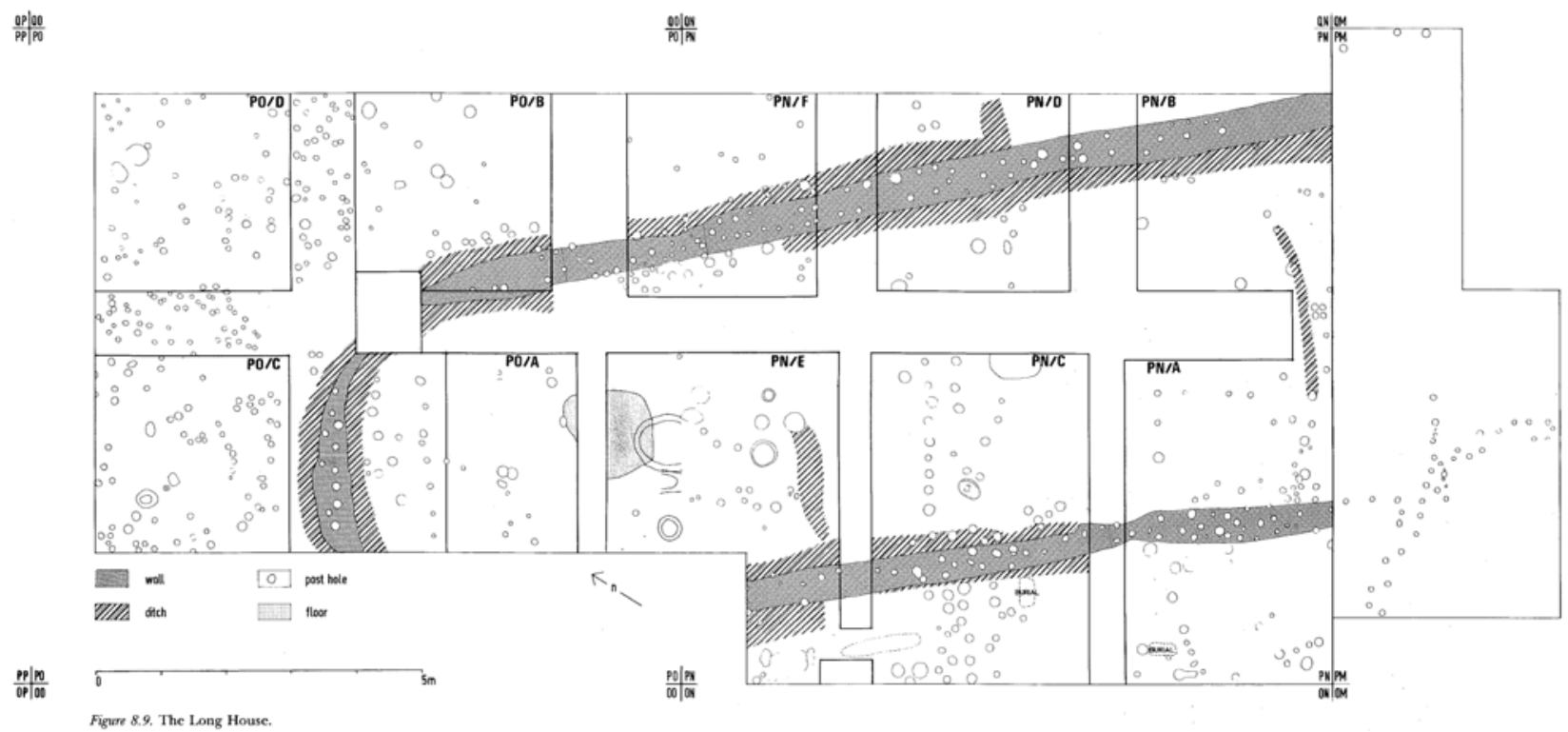

Fig. 9. The Long House (Renfrew et al. 1986, 195, Fig. 8.9). 9 pav. Ilgasis namas (Renfrew et al. 1986, 195, 8.9 pav.).

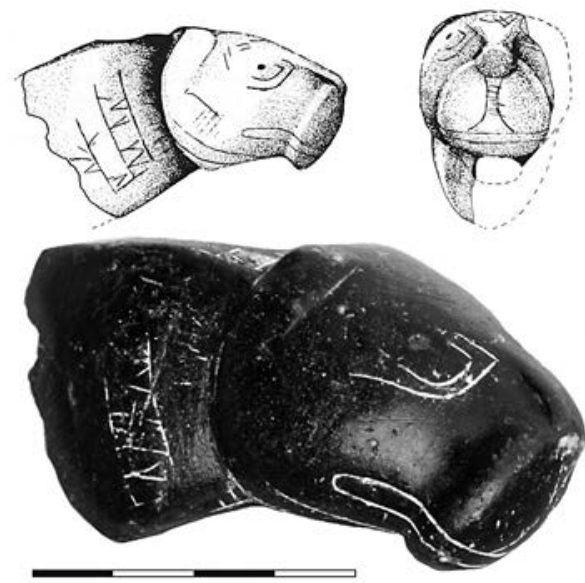

Fig. 10. The mace head (Renfrew et al. 1986, 196, Fig. 8.10). 10 pav. Kuoka (Renfrew et al. 1986, 195, 8.10 pav.).

close relationship between the two Drama plain sites and with the Chalcolithic cultures in Bulgaria and Romania: Gumelnița-Karanovo V \& VI (Renfrew 2003, 491). It was during Sitagroi Phase III that trade and exchange are strongly represented and this is precisely the time of metallurgical developments in Bulgaria (Renfrew 1969) and Varna's rich burials with gold and other precious objects, which mark Old Europe as a period not to be attained again for centuries (Renfrew 1978; 1986; Anthony 2007, 225).

Sitagroi Phase IV was transitional between the end of Chalcolithic Phase III and the onset of a different 'culture', the Early Bronze Age, Phases $\mathrm{Va}$ and $\mathrm{b}$. Trade in spondylus was very limited; the mound may have been abandoned for some time; and pottery was no longer produced in spectacular shapes and decorations. But the 'period' of Old Europe did not end at Sitagroi until a large opening at the top of the mound revealed the outline of an Early Bronze Age 'Long House' (Fig. 9). The finds inside the house were sparse aside from a remarkable polished black diorite shaft-hole axe and a mace head with a zoomorphic butt (Fig. 10), reflecting a link to the east where these mace heads are found, sometimes in Early Bronze Age male graves (Govedarica 2004; Anthony 2007, 235, Fig. 11.5; Elster 2020). Radiocarbon dates for the Phase $\mathrm{Vb}$ Long House ranged between 2055 and $2021+/-40$ BC (Renfrew 1986, 189). Almost below it, the outline 


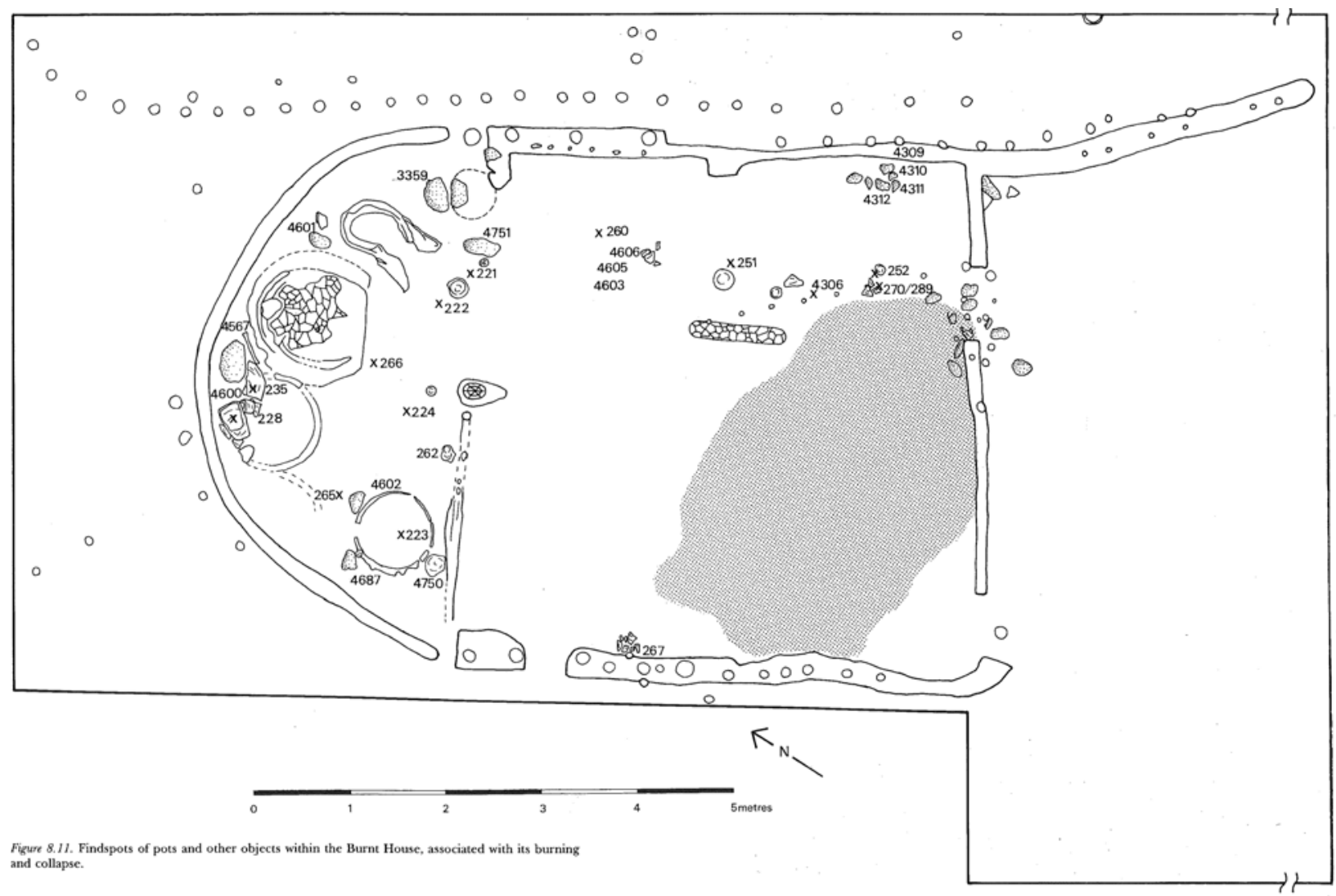

Fig. 11. The Burnt House (Renfrew et al. 1986, 166, Fig. 7.16).

11 pav. Sudegęs namas (Renfrew et al. 1986, 166, 7.16 pav.).

of an earlier, Phase Va house was exposed; the $5 \mathrm{x}$ $5 \mathrm{~m}$ 'Burnt House' had a $3 \mathrm{~m}$ 'kitchen' extension, an intact wall outline, and features such as a 'kitchen' with plaster lined bins, oven structures, bone tools, stone grinders, doorway openings, a fragment of a plaster floor, a hearth, pottery, and spindle whorls. (Fig. 11). It was as if the occupants had escaped the fire which had consumed the building but preserved many of the finds.

Many more aspects of Old Europe are reported in the two-volume studies of Sitagroi's artefacts and materials (Renfrew et al. 1986; Elster, Renfrew 2003). From Phase I and until Phase IV, Sitagroi revealed a varied collection of miniature clay figurines, in context, of animals and humans, both natural and symbolic, some masked and some not, which Marija identified as a symbolic representation of a prehistoric mythological pantheon. This was in 1968, during Sitagroi's first season; she added these to the few from Obre and Anzabegovo and the hundreds she had examined and photographed during her working visits to museums and sites all over Old Europe.

\section{OLD EUROPE}

In 1974, with the excavations of Obre, Sitagroi, and Anza closed and Achilleion underway, she published, based on findings at those sites and the many others she had documented, The Gods and Goddesses of Old Europe 7000-3500 вС Myths, Legends, \& Cult Images (Gimbutas 1974c). In her Introduction she wrote, 

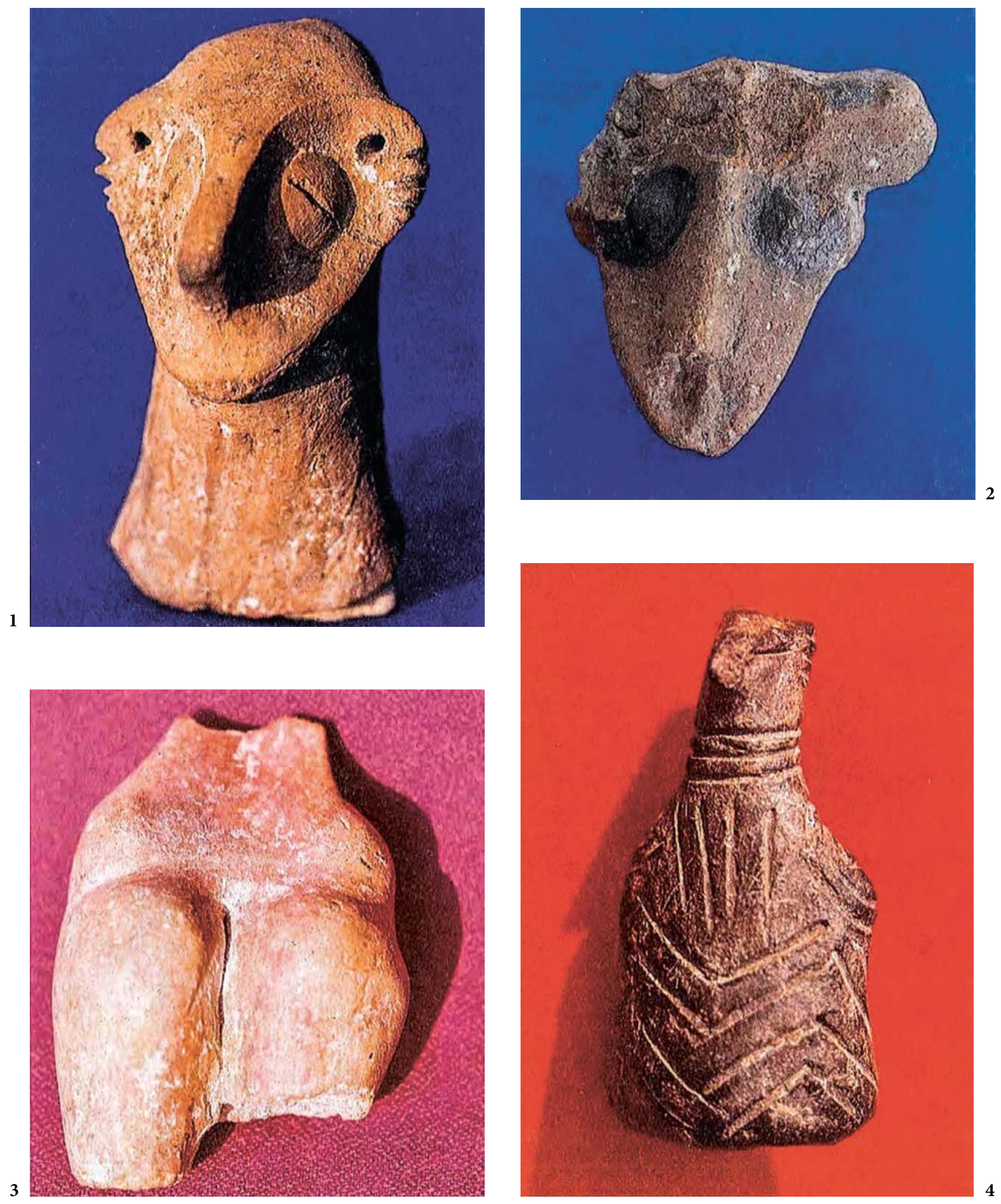

Fig. 12. Sitagroi figurines (Renfrew et al. 1986, 511, Plate A). 12 pav. Sitagroi figūrèlès (Renfrew et al. 1986, 511, A lentelè). 
'Villages depending upon domesticated plants and animals had appeared in southern Europe as early as the $7^{\text {th }}$ millennium $\mathrm{BC}$, and the spiritual forces accompanying this change in the economic and social organization are manifested in the emergent artistic tradition of the Neolithic. Old Europe is introduced here in recognition of the collective identity and achievement of the different cultural groups of Neolithic-Chalcolithic Southeastern Europe... From the Aegean and Adriatic, including the islands, then as far north as Czechoslovakia, southern Poland and the Western Ukraine.' (Gimbutas 1974c).

Marija delineated the area of Old Europe with a series of maps with sites indicated in each large region. But her focus, as the title suggests, was on the hundreds of small clay figurines from Sitagroi, Achilleion, and other sites which she interpreted as a pantheon of prehistoric gods and goddesses. It attracted an audience beyond the world of archaeology and became a best seller. I think the idea of 'Old Europe' was one of Marija's most original ideas, but it was overshadowed by its identification with the controversial figurine interpretations.

It has taken many decades for the term, Old Europe, to be recognized but it is now used very effectively (Fig. 12). For example, David Anthony was honoured with the SAA's 2010 Book Award for The Horse, the Wheel, and Language - How Bronze Age Riders from the Eurasian Steppes Shaped the Modern World (2007) in which he integrates historical linguistics and archaeology to argue (as Marija did with her kurgan hypothesis) the who, why, and when of the arrival into Europe of ${ }^{\star}$ Proto-Indo-European speakers. His index includes dozens of references to 'Old Europe' and Chapter 11 is entitled The End of Old Europe and the Rise of the Steppe; and I quote,

Marija Gimbutas called the Danubian farming cultures 'Old Europe'. The agricultural towns of Old
Europe were the most technologically advanced and aesthetically sophisticated in all of Europe between about 6000 and 4000 ВСЕ (Anthony 2007, 133).

Recently John Chapman's magnum opus (his term, but I agree) was published, Forging Identities in the Prehistory of Old Europe - Dividuals, Individuals and Communities 7000-3000 BC (Chapman 2020). In it, he defined his use of 'Old Europe':

...this sense of a geographically delimited region linked by distinctive long-term cultural practices... from 7000-3000 BC in a diverse landscape of nonmonumental settlements... with gardens, fields, pastures, pathways, routes forming networks linking communities...(with) role of objects (quantity and diversity of) vital in creating such cultural landscapes.

Clearly, Chapman considered that the amount and variation in technology and culture were significant characteristics of Neolithic-Chalcolithic Old Europe. But as pointed out (Robb 2013) objects and practices would differ from place to place and region to region (Thessaly to the Carpathians or the Maritsa Valley to the Adriatic). Nevertheless, over this large area and time period - three to four millennia hunters and foragers slowly chose a settled life of sowing, reaping, and keeping/domesticating plants and animals, what Gimbutas would recognize as the foundation of Old Europe.

Two other volumes indicate the importance of the term 'Old Europe' in identifying the large area in space and time that is under discussion: The Lost World of Old Europe: The Danube Valley, 5000-3500 BC (Anthony, Chi, 2010) published in conjunction with a brilliant exhibit organized by the Institute for the Study of the Ancient World at New York University; and A Short History of Humanity: A New History of Old Europe (Krause, Trappe 2021) which focuses on aDNA and the peopling of Europe and introduces archaeogenetics 


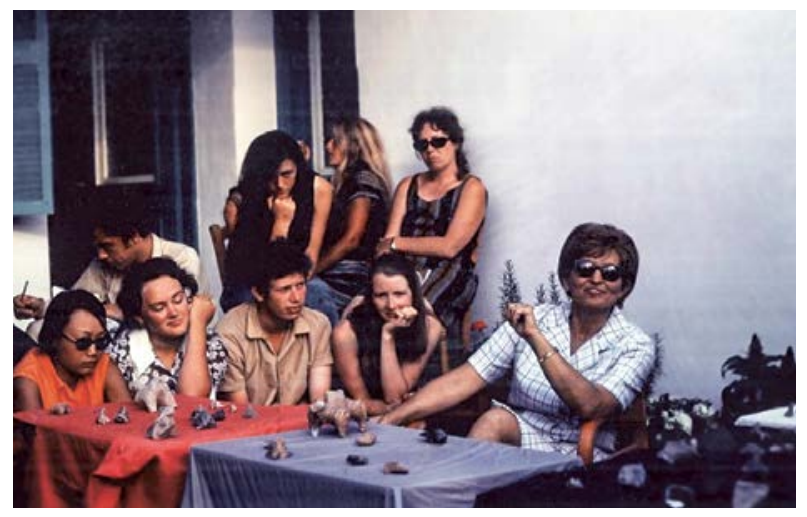

Fig. 13. A seminar presented by Marija Gimbutas in Sitagroi village in 1968; audience, excavation teams from Sitagroi and Dikili Tash. Photo by Ernestine S Elster.

13 pav. Marijos Gimbutienès seminaras Sitagroi kaimelyje. 1968. Klausytojai ir archeologinių tyrimų Sitagroi ir Dikili Taš komandos. Ernestine S. Elster nuotr.

\section{THE PANTHEON}

Old Europe has become the rightly descriptive term for a long period, the Neolithic to the Chalcolithic, and a large region. That the region seems to carry with it, from the Aegean to the Danube and from west to east, hundreds of sites virtually all revealing a few or many human, male and female, natural and/or symbolic figurines, mostly formed in clay, that are similar in appearance, yet distinctive at every site, sometimes uncovered in or under a house or in a pit, broken or unbroken, figurines that led to the creation of Marija Gimbutas' 'pantheon'.

When, in 1974, the title was reversed to read Goddesses and Gods of Old Europe: Myths and Cult Images, Marija Gimbutas was linked to a moment in cultural history: Ms. magazine was established by Gloria Steinem (1972) and the writings of feminists Betty Friedan (1963), Kate Millet (1968), and Simone de Beauvoir (1949; 2009) were front page and political. Some feminists interpreted Goddesses and Gods as indicating that in prehistory, god was a woman or at least men and women were equally in positions of power. Her critics felt she was not helping feminists fighting to make gender more equally treated in the workplace or efforts to scientifically identify gender in the archaeological record but rather presented ideas of females as mothers, nurses, and even goddesses, all traditional female roles in a patriarchal world (Tringham, Conkey 1998). Controversy ensued; she was hailed for the wonderful images presented and the carefully organized and illustrated pantheon (e.g. Jakar 1993; Phillips 1993) and roundly criticized for what was referred to as her personal and romantic identification of these sculptures (e.g. Talalay 1994a). Marija infuriated academia because she didn't present her ideas with a cloak of ambiguity - instead, she was quite certain. In the end she paid no attention to her critics (Renfrew 1991; Fagan 1992) and introduced studies (Winn, Shan Milton McChesney 1981) of an Old Europe proto-script in the expanded pantheon publications (Gimbutas 1989; 1991; Gimbutas, Dexter 1999). She had been carried aloft, a recognized academic, whose studies offered feminists a time when female was central, quite opposite to the basic 'god the father'. Marija's goddess writings have generated passionate positive and negative responses (cf. references Elster 2015) but the recent thoughtful work is an attempt to understand and explain the role of the small sculptures in Old Europe and thus, to reply to Marija's pantheon (see especially Kokkinidou 2020).

Three decades now after her death, I think she has left an impressive series of excavations (Fig. 13) and absolutely fearless identification of a prehistoric pantheon in an area that she delineated and that is now recognized as Old Europe. Towards the end of her life, rather personally removed from the controversy and with her background in mythology, folklore, archaeology, folktale, and ethnic studies, she referred to herself as an 'archaeo-mythologist', thus introducing a new field.

During the conferences, in which I participated and which celebrated UNESCO's 2021 Centennial list honouring Marija Gimbutas, some interesting 
ideas were offered in relation to the pantheon, recognizing its value as generating entirely new ways of thinking.

In the Lithuanian Conference (Vilnius 2021): Douglas Bailey, 'Beyond the Critique of Anecdotal Explanation: Marija Gimbutas' archeo-mythology of Prehistoric Figurines as Art/Archaeology' wherein he explained that Marija Gimbutas stepped over the accepted presentation of archaeological data (by not offering testable analyses of her hypotheses ) and thus created a new discipline, archeo-mythology; Peter Biehl, 'The Symbolism of Anthropomorphic Figurines and their Fragmentation', with many illustrations of female figurines from Catalhuyuk West and other Turkish Neolithic sites, described the masked figurines as inspiration for artists and choreographers who joined to produce a dancemuseum exhibition - the dancers masked as were some of the 'goddesses'. Here he presented archaeology entering art. The University of Washington Baltic Studies Conference (Seattle 2021) sponsored a panel, 'The Feminist Anthropology of Old Europe: Celebrating the Centennial of Marija Gimbutas (1921-2021)' presenting Rasa Navickaite's 'Goddess Archaeology: Marija Gimbutas, Feminism, and the Construction of the Eastern European Heritage' in which she reviewed, analyzed, and evaluated Gimbutas' influence, its political undercurrent, and its inspiration for eco-feminism in the West and East. With her talk Navickaite connected Marija with the cultural-spiritual feminist movement as a stimulus and 'god mother' (see especially Dexter, Noble 2015).

To summarize, Marija Gimbutas leaves behind 40 years of ${ }^{\star}$ PIE research and her now viable 'kurgan' hypothesis, supported by aDNA; her explanation of culture change, attributing the arrival of * PIE speakers in Europe with the transformation of Old Europe society and its gender relations (as represented by the pantheon); Old Europe's identification in space, time, and form - three to four millennia from the
Early Neolithic to the Chalcolithic with its pantheon of gods and goddesses leading to archaeo-mythology, a partnership of art and archaeology, and spiritual feminism. Her recognition on the 2021 UNESCO Centennial list could not be more appropriate.

\section{REFERENCES}

Anthony, D., 2007. The Horse, the Wheel and Language. How Bronze-Age Riders from the Eurasian Steppes Shaped the Modern World. Princeton University Press.

Anthony, D. W., Chi, J. Y., (eds), 2010. The lost world of Old Europe. The Danube valley, 50003500 BC. New York: Institute for the Study of the Ancient World.

Beauvoir, Simone de, 2009 [1949]. The Second Sex. Trans. Constance Borde and Sheila MalovanyChevallier. Random House: Alfred A. Knopf.

Benac, A., 1973. Obre I and II, Wissenschaftliche Mitteilungen des Bosnisch-Herzegowinischen Landesmuseums, Band III, Heft A. Sarajevo: Zemalski Museum.

Binford, L. R., 1962. Archaeology as Anthropology. American Antiquity, 28, 2, 217-225.

Bökönyi, S., 1974. History of Domestic Mammals in Central Eastern Europe. Budapest: Akademiai Kiodó.

Bökönyi, S., 1986. Faunal Remains. In: Renfrew, C., Gimbutas, M., Elster, E. S., (eds). Sitagroi, Vol 1 (= Monumenta Archaeologica 13). Los Angeles: Cotsen Institute of Archaeology UCLA, 63-132.

Bradford, J., 1949. Buried Landscapes in Southern Italy. Antiquity, 23, 58-72.

Chapman, J., 2020. Forging Identities in the Prehistory of Old Europe: Dividuals, Individuals and Communities, 7000-3000 BC. Leiden: Sidestone Press.

Deshayes, J., Treuil, R., (ed.), 2004. Dikili Tash: Village Préhistorique de Macédoine Orientale Fouilles de Jean Deshayes (1961-1975) Volume 2. Athènes: École Française d'Athènes. 
Dexter, M. R., Noble, V., 2015. Foremothers of the women's spirituality movement: elders and visionaries. Amherst, New York: Teneo Press.

Elster, E. S., 2004. Figuring Out Social Archaeology at Sitagroi. In: Cherry, J., Scarre, C., Shennan, S., (eds). Explaining Social Change: Studies in Honor of Colin Renfrew. Cambridge University: McDonald Institute Monographs, 81-91.

Elster, E. S., 2007. Marija Gimbutas: Setting the Agenda. In: Hamilton, S., Whitehouse, R. D., Wright, K. I., (eds). Archaeology and Women - Ancient and Modern Issues. Walnut Creek: Left Coast Press, CA, 83-120.

Elster, E. S., 2015. Marija Gimbutas: Old Europe, Goddesses and Gods, and the Transformation of Culture. BACKDIRT, 94-102.

Elster, E. S., Renfrew, C., (eds), 2003. Prehistoric Sitagroi: Excavations in Northeast Greece 19681970, Volume 2: The Final Report (= Monumenta Archaeologica 20). Los Angeles: Cotsen Institute of Archaeology at UCLA.

Elster, E. S., Robb, J. D., Isetti, E., Traverso, A., (eds), 2016. Archaeology of Grotta Scaloria: Ritual in Neolithic Southeast Italy (=Monumenta Archaeologica 38). Los Angeles: The Cotsen Institute of Archaeology Press.

Evans, R. K., 1986. The Pottery of Phase III. In: Renfrew, C., Gimbutas, M., Elster, E. S., (eds). Sitagroi, Vol 1, (=Monumenta Archaeologica 13). Los Angeles: Cotsen Institute of Archaeology UCLA, 393-427.

Fagan, B., 1992. A sexist view of prehistory: Review of The Civilization of the Goddess by M. Gimbutas. Archaeology, 45 (2), 16-18, 66.

Friedan, B., 1963. The Feminine Mystique. W. W. Norton \& Company.

Gimbutas, M., 1956. The Prehistory of Eastern Europe Part 1: Mesolithic, Neolithic, and Copper Age Cultures in Russia and the Baltic Area. Cambridge, Mass: Peabody Museum.
Gimbutas, M., 1965. Bronze Age cultures in Central and Eastern Europe. Berlin: De Gruyter Mouton.

Gimbutas, M., 1972. Excavation at Anza, Macedonia: Further insight into the civilization of Old Europe, 7000-4000 B.C. Archaeology, 25, 112-123.

Gimbutas, M., 1974a. Obre and Its Place in Old Europe. Wissenschaftliche Mitteilungen des Bosnisch-Herzogowinischen Landesmuseums, Band IV Heft A, Sarajevo: Zemalski Museum

Gimbutas, M., 1974b. The Mask in Old Europe, 6500-3500 вс. Archaeology, 27, 262-69.

Gimbutas, M., 1974c. Gods and Goddesses of Old Europe: 7000-3500 вс. London: Thames and Hudson.

Gimbutas, M., 1976. Neolithic Macedonia as Reflected by Excavations at Anza, Southeast Yugoslavia (=Monumenta Archaeologica 1). Los Angeles: UCLA, Institute of Archaeology.

Gimbutas, M., 1982. Goddesses and Gods of Old Europe: Myths and Cult Images. London: Thames and Hudson.

Gimbutas, M., 1989. The Language of the Goddess. San Francisco: Harper and Row.

Gimbutas, M., 1991. The Civilization of the Goddess: The World of Old Europe. San Francisco: Harper and Row.

Gimbutas, M., Dexter, M. R., (eds), 1999. The Living Goddesses. Los Angeles: University of California Press.

Gimbutas, M., Shimabuku, D., Winn, S., 1989. Achilleion, A Neolithic Settlement in Thessaly, Greece 6500-5400 BC (=Monumenta Archaeologica 14). Los Angeles: Institute of Archaeology, UCLA.

Govedarica, B., 2004. Zepterträger - Herrscher der Steppen die frühen Ockergräber des älteren Äneolithikums im karpatenbalkanischen Gebiet und im Steppenraum Südost- und Osteuropas. Mainz am Rhein: Verlag Philipp Von Zabern.

Jakar, J., 1993. Review of the Civilization of the Goddess: The World of Old Europe. Bulletin of American Schools of Oriental Research, 292, 122. 
Kokkinidou, D., 2020. In Pursuit of the Goddess: Neolithic Imagery, Marija Gimbutas, and Debates in Feminism and Archaeology. In: Brent, D., Laffineur, R., (eds). Studies in Bronze Age Aegean Art and Archaeology in Honor of Professor John G. Younger on the Occasion of His Retirement (=Annales d'Archéologie Liégeoises Et PASPiennes, Aegaeum 44). Leuven - Liège: Peeters, 67-80.

Koukoulē-Chrysanthakē, H., Treuil, R., Lespez, L., Malamidou D., 2008. Dikili Tash, village préhistorique de Macédoine orientale: recherches franco-helléniques dirigées par la Société Archéologique d'Athènes et l'École française d'Athènes (1986-2001): Le programme de recherches. Athènes: Hē en Athēnais Archaiologikēs Hetaireias.

Krause, J., Trappe, T., 2021. A Short History of Humanity: A New History of Old Europe. New York: Random House.

Millett, K., 1968. Sexual Politics. Boston: New England Free Press.

Navickaitè, R., 2019. The Prehistoric Goddess of the Late Twentieth Century: Transnational Feminist Reception, Construction, and Appropriation of Marija Gimbutas (Doctoral dissertation). Budapest: Central European University.

Nikolaidou, M., 2003. Items of Adornment. In: Elster, E. S., Renfrew, C., (eds). Sitagroi, Vol 2 (= Monumenta Archaeologica 20). Los Angeles: Cotsen Institute of Archaeology, UCLA, 331-360.

Phillips, P., 1993. Review of The Civilization of the Goddess: The World of Old Europe. Proceedings of the Prehistoric Society, 59, 410-411.

Renfrew, C., 1969. The Autonomy of the Southeast European Copper Age. Proceedings of the Prehistoric Society, 35, 12-47.

Renfrew, C., 1978. Varna and the Social Context of Early Metallurgy. Antiquity, 52, 199-203.

Renfrew, C., 1986. Varna and the Emergence of Wealth in Prehistoric Europe. In: Appadurai, A., (ed.). The Social Life of Things. Cambridge: Cambridge University Press, 141-168.
Renfrew, C., 1991. Review of Marija Gimbutas, 1989, 'The Language of the Goddess'. Proceedings of the Prehistoric Society, 57, 222-223.

Renfrew, C., Elster, E. S., 2003. Concluding Observations. In: Elster, E. S., Renfrew, C., (eds). Sitagroi, Vol 2 (=Monumenta Archaeologica 20). Los Angeles: Cotsen Institute of Archaeology, UCLA, 489-493.

Renfrew, C., Gimbutas, M., Elster, E. S., (eds), 1986. Excavations at Sitagroi: A Prehistoric Village in Northeast Greece Vol. 1 (=Monumenta Archaeologica 13). Los Angeles: Cotsen Institute of Archaeology, UCLA.

Renfrew, J., 2003. Grains, Seeds, and Fruits from Prehistoric Sitagroi. In: Elster, E. S., Renfrew, C., (eds). Sitagroi, Vol 2 (=Monumenta Archaeologica 20). Los Angeles: Cotsen Institute of Archaeology, UCLA, 3-28.

Robb, J., 2013. Material Culture, Landscapes of Action, and Emergent Causation A New Model for the Origins of the European Neolithic. Current Anthropology, 54, 657-683.

Shackleton, N., Renfrew, C., 1970. Neolithic trade routes re-aligned by oxygen isotope analysis. Nature, 228 (5276), 1062-1065.

Steinem, G., 1972. Ms. New York: Liberty Media for Women.

Sterud, G., Sterud, A., 1974. A Quantitative Analyses of the Material Remains. Wissenschaftliche Mitteilungen des Bosnisch-Herzogowinischen Landesmuseums, Band IV Heft A, Sarajevo: Zemalski Museum, 155-355.

Tafuri, M. A., O’Connell, T. C., Robb, J., Knüsel, C., Fullagar, P., 2016. Mobility, Landscape and the Function of the Cave: Evidence from Strontium Isotopes. In: Elster, E. S., Isetti, E., Robb, J., Traverso, A., (eds). Archaeology of Grotta Scaloria: Ritual in Neolithic Southeast Italy (=Monumenta Archaeologica 38). Los Angeles: Cotsen Institute of Archaeology Press, 139-144. 
Talalay, L., 1994a. A feminist boomerang: The Great Goddess of Greek prehistory. Gender and History, 6 (2), 165-183.

Talalay, L., 1994b. Deities, Dolls, and Devices: Neolithic Figurines from Franchthi Cave, Greece, Excavations at Franchthi Cave, Greece, Fascicle 9. Bloomington: Indiana University Press.

Tringham, R., 2003. Flaked Stone. In: Elster, E. S., Renfrew, C., (eds). Sitagroi, Vol 2 (=Monumenta Archaeologica 20). Los Angeles: Cotsen Institute of Archaeology, UCLA, 81-126.
Tringham, R., Conkey, M., 1998. Rethinking figurines: A critical view from archaeology of Gimbutas, the 'Goddess' and popular culture. In: Goodison, L., Morris, C., (eds). Ancient Goddesses. London: British Museum Press, 22-45.

Winn Shan, M. M., 1981. Pre-Writing in Southeast Europe: The Sign System of the Vinča Culture, ca. 4000 вс. Calgary: Western Publishers. 